\title{
Spermine Sepharose as a clustered-charge anion exchange adsorbent
}

\author{
Sagar Dhamane ${ }^{a}$, Federico Ruiz-Ruiz ${ }^{\mathrm{a}, \mathrm{b}}$, Wen-hsiang Chen ${ }^{\mathrm{c}}$, Katerina Kourentzi ${ }^{\mathrm{c}}$, \\ Jorge Benavides ${ }^{\mathrm{b}}$, Marco Rito-Palomares ${ }^{\mathrm{b}}$, Richard C. Willson ${ }^{\mathrm{a}, \mathrm{b}, \mathrm{c}, *}$ \\ a Department of Biology \& Biochemistry, University of Houston, Houston, TX 77204-5001, USA

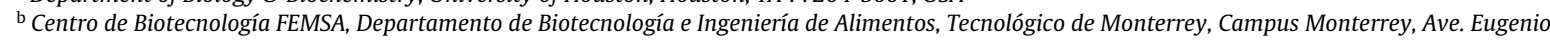 \\ Garza Sada 2501 Sur, Monterrey, NL 64849, Mexico \\ ${ }^{\mathrm{c}}$ Department of Chemical E' Biomolecular Engineering, University of Houston, Houston, TX 77204-4004, USA
}

\section{A R T I C L E I N F O}

\section{Article history:}

Received 5 August 2013

Received in revised form

10 November 2013

Accepted 13 November 2013

Available online 20 November 2013

\section{Keywords:}

Ion-exchange chromatography

Clustered charge

Adsorption

Spermine

Ligand density

\begin{abstract}
A B S T R A C T
We previously showed that the affinity and capacity of ion exchange adsorbents of a given total charge density are improved by immobilization of the charges in pre-ordered clusters, rather than individually in random locations. This previous work used pentalysinamide and pentaargininamide as clustered ligands. This approach allows close control of cluster size, but is uneconomically expensive for some research and most practical applications. In this work, we demonstrate that the inexpensive synthetic analog of the natural polyamine spermine $\left(\mathrm{H}_{2} \mathrm{~N}-\mathrm{CH}_{2}-\mathrm{CH}_{2}-\mathrm{CH}_{2}-\mathrm{NH}-\mathrm{CH}_{2}-\mathrm{CH}_{2}-\mathrm{CH}_{2}-\mathrm{CH}_{2}-\mathrm{NH}-\mathrm{CH}_{2}-\mathrm{CH}_{2}-\mathrm{CH}_{2}-\mathrm{NH}_{2}\right)$ also can serve as the basis of effective clustered adsorbents. The calcium-depleted form of the protein $\alpha$-lactalbumin, and RNA from baker's yeast, were adsorbed on a spermine Sepharose adsorbent. This adsorbent exhibited enhanced $\alpha$-lactalbumin binding capacity $\left(Q_{\max }>1.6\right.$ and 1.3 -fold higher than those for Qiagen DEAE and GE DEAE Sepharose adsorbents of much greater charge density) and higher initial binding affinity $\left(Q_{\max } / K_{\mathrm{D}} 2.4\right.$ and 2.1 -fold higher, respectively). The new spermine-based matrix exhibited a higher value of the $Z$ parameter, suggesting an increased number of apparent interaction sites between the protein and the resin, and functioned well in column mode.
\end{abstract}

(C) 2013 Elsevier B.V. All rights reserved.

\section{Introduction}

The steady increase in titers and sales of recombinant pharmaceutical proteins have increased interest in high-efficiency, high-capacity downstream processes for the recovery and purification of biological products [1-3], particularly since estimates of the fraction of bioprocess costs devoted to purification range as high as $80 \%$ [4-6]. The continuing need for selective, scalable and economical unit operations has driven the design of novel bioengineering strategies $[7,8]$.

Chromatographic purification remains the most costly element of biopharmaceutical downstream processing [9,10], and development of optimal chromatographic processes is a central issue in bioprocess engineering. Because it offers strong and easily reversible protein adsorption, ion-exchange chromatography is widely used for the selective purification of biomolecules $[11,12]$. Traditional ion-exchange adsorbents present a random charge distribution over the particle surface that creates a heterogeneous field

\footnotetext{
* Corresponding author at: Department of Chemical \& Biomolecular Engineering, University of Houston, Houston, TX 77204-4004, USA. Tel.: +1 713743 4308; fax: +1 7137434323 .

E-mail address: willson@uh.edu (R.C.Willson).
}

of adsorption sites [13]. In order to improve this random charge distribution for protein capture, adsorbents have been modified in the past to present improved characteristics by either increasing ligand density through the use of tentacular adsorbents $[14,15]$ or by attaching polyions such as polyethyleneimine or polylysine in order to enhance product selectivity and recovery [16].

Many proteins present a characteristic high charge-density patch that can play a dominant role in the ion-exchange adsorption of these molecules [11,17-19]. We have found that an adsorbent displaying uniform clusters of positive charge shows a higher affinity and capacity for negatively charged biomolecules than an adsorbent with the same total charge density displayed as dispersed charges $[11,20]$. Clustered pentaargininamide adsorbents of relatively low ligand density show higher affinity for negatively charged proteins than conventional adsorbents of much higher ligand density [11]. The use of pentaargininamide as a ligand in research and for process scale purification, however, must contend with the cost and base-lability of the ligand, which hampers efficient resin cleaning. In this work we describe spermine as an inexpensive, stable ligand for clustered adsorbents. Spermine is a polycationic polyamine involved in DNA packaging whose four amines (see Fig. 1) can form a cluster of four positive charges [21], and whose low cost and alkali stability make it potentially suitable as a ligand for clustered-charge anion exchange chromatography. 


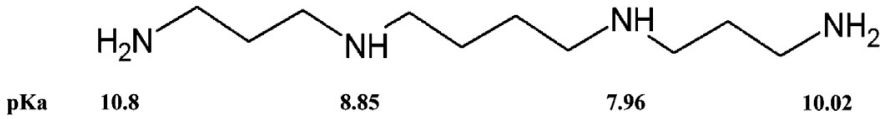

Fig. 1. Spermine molecule with corresponding $\mathrm{p} K_{\mathrm{a}}$ values for titratable atoms. Note that $\mathrm{p} K_{\mathrm{a}}$ values for symmetry-related atoms differ because of the sequential addition of protons to the molecule.

In the present work we demonstrate the superior affinity and capacity of a spermine Sepharose clustered-charge anion exchanger for the anionic protein $\alpha$-lactalbumin, which presents a modifiable charge cluster. The clustered-charge adsorbent presents enhanced initial binding affinity $\left(Q_{\max } / K_{\mathrm{D}}\right)$ and maximum binding capacity $\left(Q_{\max }\right)$ when compared to dispersed-charge commercial adsorbents, even when the latter have higher ligand density.

\section{Materials and methods}

\subsection{Materials}

Sepharose CL-6B, Q Sepharose Fast Flow and DEAE Sepharose were from GE Healthcare (Piscataway, NJ). DEAE Plasmid Plus resin was from Qiagen (Valencia, CA). All other reagents were from Sigma Aldrich (St. Louis, MO) including salmon sperm DNA (Cat. number: D1626), Baker's yeast RNA (Cat. number: R6750) and $\mathrm{Ca}^{2+}$ depleted $\alpha$-lactalbumin from bovine milk (Cat. number: L6010). $\alpha$-Lactalbumin was prepared from unpasteurized bovine milk and was purified by ion exchange chromatography on DEAE-agarose. Its purity is $\geq 85 \%$ as was determined by PAGE. The molar mass for the protein used was $14,100 \mathrm{~g} / \mathrm{mol}$ and the extinction coefficient $\varepsilon^{1 \%}=20.1[22]$.

\subsection{Adsorbent preparation}

Aldehyde activation of Sepharose was based on the method of Miron and Wilchek [23]. For activation, DI water-washed Sepharose $\mathrm{CL}-6 \mathrm{~B}$ ( $400 \mu \mathrm{l}$ in $1.6 \mathrm{~mL}$ water) was treated with $0.2 \mathrm{M}$ sodium periodate for $3 \mathrm{~h}$ at room temperature, then washed with DI water and resuspended in $50 \mathrm{mM}$ borate buffer $\mathrm{pH} 9.5 \pm 0.2$. To $400 \mu \mathrm{l}$ of activated Sepharose CL-6B settled resin, $1.6 \mathrm{~mL}$ of spermine tetrahydrochloride $(45 \mathrm{mg} / \mathrm{mL})$ solution in $50 \mathrm{mM}$ borate buffer, $\mathrm{pH}$ 9.5 was added and incubated on a gyratory rotator at room temperature for $2 \mathrm{~h}$ and centrifuged $2 \mathrm{~min}$ at $16,000 \times \mathrm{g}$. The gel with the bound spermine was treated for $3 \mathrm{~h}$ with $2 \mathrm{~mL}$ of $2 \mathrm{mM}$ sodium borohydride in $50 \mathrm{mM}$ borate buffer, $\mathrm{pH} 9.5$ to reduce the initially formed Schiff base into a stable secondary amine linkage. Spermine modified Sepharose was washed with $20 \mathrm{mM}$ phosphate buffer, $\mathrm{pH}$ 7.0 and stored at $4{ }^{\circ} \mathrm{C}$.

\subsection{Ligand density determination}

The ligand density of spermine Sepharose was determined by titration with $5 \mathrm{mM} \mathrm{NaOH}$ in column mode using an ÄKTA purifier FPLC equipped with a post-column $\mathrm{pH}$ monitor. Spermine Sepharose was packed in a column $(5 \times 20 \mathrm{~mm})$ and equilibrated with 5 column volumes of $0.1 \mathrm{M} \mathrm{HCl}$, and then $5 \mathrm{mM} \mathrm{NaOH}$ was run through a bypass in order to equilibrate the extra-column volume. After the equilibration, $5 \mathrm{mM} \mathrm{NaOH}$ was passed through the column to determine the moles of base required to titrate the acidified adsorbent. The amount of $5 \mathrm{mM} \mathrm{NaOH}$ required for titration of unmodified Sepharose (typically about $1.2 \mathrm{~mL}$ ) was subtracted from that required to titrate the spermine Sepharose (typically about $6.8 \mathrm{~mL}$ ) to obtain the millimoles of $\mathrm{NaOH}$ used to titrate spermine.

\subsection{Adsorption isotherm measurements}

Aliquots $(25 \mu \mathrm{l})$ of $60 \%(\mathrm{v} / \mathrm{v})$ spermine Sepharose suspension in binding buffer (10 mM Tris, $10 \mathrm{mM} \mathrm{NaCl}, \mathrm{pH} 8$ ) were placed in $1.5 \mathrm{~mL}$ Eppendorf tubes. To these tubes different amounts of protein stock solution $\left(10-180 \mu \mathrm{l}\right.$ of $5 \mathrm{mg} / \mathrm{mL} \mathrm{Ca}^{2+}$-depleted bovine $\alpha$-lactalbumin (or RNA) in binding buffer) were added, followed by binding buffer up to $1 \mathrm{ml}$. Tubes were placed on a gyratory rotator at room temperature for $1 \mathrm{~h}$, then centrifuged for $10 \mathrm{~min}$ at $16,000 \times g$. Protein concentration in the supernatant was quantified by $280 \mathrm{~nm}$ absorbance using a Tecan Infinite M200 Pro microplate reader (Tecan, USA). The adsorbent pellets were washed with $1 \mathrm{~mL}$ of binding buffer followed by recentrifugation (the wash contained only a small fraction, $3.1 \% \pm 1.7 \%$, of the added protein). Bound protein was eluted with $1 \mathrm{~mL}$ of elution buffer (binding buffer $+1 \mathrm{M}$ $\mathrm{NaCl}$ ) and adsorbed protein content was determined. In order to determine the completeness of protein recovery, mass balances were performed by dividing the sum of the protein remaining in the supernatant after adsorption equilibration + protein recovered in the wash + protein in the elution fraction, by the original amount of protein added. The ionic strength of the $10 \mathrm{mM}$ Tris buffer, $10 \mathrm{mM}$ $\mathrm{NaCl}, \mathrm{pH} 8$ is estimated at $0.015 \mathrm{M}$.

\subsection{Data analysis}

The mass balance recoveries for all points in all experiments closed in the range $86-111 \%$. Protein adsorption data were fit to the Langmuir (Eq. (1)), Langmuir-Freundlich (Eq. (2)) isotherms and the steric mass action (SMA) model of Cramer et al. (Eq. (3)) [24].

$y=\frac{Q_{\max } X}{K_{\mathrm{D}}+X}$

$y=\frac{Q_{\max } X^{n_{H}}}{K^{n} H+X^{n} H}$

$y=\left(\frac{Q_{\alpha}}{K}\right)\left(\frac{X}{\Lambda-(v+\sigma) Q_{\alpha}}\right)^{v}$

In these equations, $y$ is the bound protein concentration, $X$ is the free protein concentration, $Q_{\max }$ is the maximum binding capacity (in $\mu \mathrm{mol} / \mathrm{ml}$ of settled bed adsorbent), and $K_{\mathrm{D}}$ is the dissociation constant. In Eq. (2), $n_{\mathrm{H}}$ is the Langmuir-Freundlich heterogeneity parameter. In Eq. (3), $Q_{\mathrm{a}}$ is the equilibrium adsorbent-bound protein concentration, $\mathrm{K}$ is the equilibrium constant, $\Lambda$ is the total ionic capacity of the adsorbent in $\mu \mathrm{mol} / \mathrm{ml}$ of settled bed adsorbent, $\sigma$ is the dimensionless steric factor that reflects the number of sites on the surface that are shielded by the adsorbate and prevented from exchange with salt counter-ions in solution and $v$ is the dimensionless characteristic charge that reflects the number of sites that the protein interacts with on the surface. Fitting used Igor Pro (WaveMetrics, Lake Oswego, OR; version 6.05) which uses the Levenberg-Marquardt algorithm to search for parameters which minimize the $\chi^{2}$ values, as described previously $[11,20]$. The initial guess vectors for the parameters were varied manually to ensure that a true global optimum was found.

Boardman and Partridge [25] and Regnier [26] have described the stoichiometric displacement model which emphasizes the importance of electrostatic interactions between proteins and adsorbents in terms of ionic equilibria. If an electrolyte such as $\mathrm{NaCl}$ is used, the equilibrium of $\mathrm{Na}^{+}$ions and target proteins (a polyion represented by $\mathrm{P}^{n+}$ ) between the mobile phase $(\mathrm{m})$ and the adsorbent (ad) can be represented by: $Z \mathrm{Na}_{\mathrm{ad}}+\mathrm{P}_{\mathrm{m}} \leftrightarrow \mathrm{P}_{\mathrm{ad}}+Z \mathrm{Na}_{\mathrm{m}}$. Beginning with this equilibrium an expression was derived which relates the binding affinity of the adsorbent to the molarity of the displacing salt in the mobile phase which was then linearized to the 
form $[11,25,26]: \log \left[K^{\prime}\right]=Z \log [\mathrm{NaCl}]+\log [I]$ where $K^{\prime}$ is the initial binding affinity of the adsorbent, $I$ is a constant and $Z$ represents the number of counter ions displaced when a target protein is adsorbed on the resin surface. This also has been interpreted as the number of chemical interactions between the adsorbate and the adsorbent $[11,27]$, though we have shown that $Z$ can be fractional and can vary with temperature [19]. When the initial binding affinities of the proposed adsorbents at different $\mathrm{NaCl}$ concentrations are plotted, a $Z$-plot can be generated and the negative value of the slope of this graph gives the respective $Z$ value. Finally, the $Z$ values for adsorption of $\alpha$-lactalbumin on the proposed clustered adsorbent and a commercial non-clustered adsorbent (Qiagen DEAE) were calculated.

\subsection{Column chromatography}

Column chromatography experiments were performed using a glass column ( $21 \mathrm{~mm} \mathrm{H} \times 5 \mathrm{~mm}$ ID) packed with the anion exchange adsorbent. The column was initially equilibrated with 5 column volumes (CV) of buffer A (10 mM Tris, $10 \mathrm{mM} \mathrm{NaCl}, \mathrm{pH} 8.0) .1 \mathrm{ml}$ of a protein mixture containing equal amounts of $\mathrm{Ca}^{2+}$ depleted $\alpha$ lactalbumin $(0.2 \mathrm{mg}$ ) and bovine serum albumin (BSA; $0.2 \mathrm{mg}$ ) were loaded on the column. The column was washed with $5 \mathrm{CV}$ of Buffer A (10 mM Tris, $10 \mathrm{mM} \mathrm{NaCl}, \mathrm{pH} 8.0$ ), then sample was eluted over $25 \mathrm{CV}$ with a linear gradient from Buffer A to Buffer A+250 mM $\mathrm{NaCl}$. All experiments were carried out at $4{ }^{\circ} \mathrm{C}$ on an ÄKTA purifier 10 (GE Healthcare, Uppsala, Sweden). The proteins were identified based on their retention times when run separately on the same column.

\section{Results and discussion}

\subsection{Adsorbent preparation}

The four $\mathrm{p} K_{\mathrm{a}}$ values of spermine are $7.96,8.85,10.02$, and 10.80 , with the higher $\mathrm{p} K_{\mathrm{a}} \mathrm{s}$ corresponding to the terminal amines $[21,28]$. We used SPARC to estimate that in the linkage created by conjugation of spermine to Sepharose by the periodate method $\left[\mathrm{OH}-\mathrm{CH}_{2}-\mathrm{CH}_{2}-\mathrm{CH}(\mathrm{OH})-\mathrm{O}-\mathrm{CH}_{2}-\mathrm{CH}_{2}-\mathrm{H}_{2} \mathrm{~N}-\mathrm{CH}_{2}-\ldots\right]$ the $\mathrm{p} K_{\mathrm{a}}$ of the coupled nitrogen is near 9.39; this implies that all four groups should be significantly protonated at the working $\mathrm{pH}$ of this investigation, $\mathrm{pH}$ 8.0. According to the Henderson-Hasselbalch equation, at $\mathrm{pH} 8.0$, the spermine molecule conjugated to Sepharose has 3.3 charges/molecule.

In this initial work, we chose to prepare spermine Sepharose with a relatively low ligand density (typically $17 \mathrm{mM}, 68 \mathrm{mM}$ protonatable nitrogens) in order to avoid a heterogeneous landscape of interacting adsorption sites as found in traditional ion exchange adsorbents. As mentioned above [11], clustered-charge adsorbents such as the spermine Sepharose used in this work, differ from the tentacular ion exchange adsorbent matrix $[11,14]$. In a tentacular ion exchange adsorbent, accessibility of the ligand is improved by using long linear polymer chains, which carry the functional ligands. In the case of clustered-charge adsorbents like spermine Sepharose, the ligand itself is a small charged polymer which forms a cluster of positive charges.

Sepharose CL-6B was chosen as a base matrix since it offers a hydrophilic surface and can be easily activated with sodium periodate to a controlled degree, as reported elsewhere [23]. The terminal amines of spermine have $\mathrm{p} K_{\mathrm{a}} \mathrm{s}$ of 10.02 and 10.8 , and the internal amines have $\mathrm{p} K_{\mathrm{a}} \mathrm{s} 7.96$ and 8.85 [28]. In order to achieve low ligand density by rendering some potentially reactive amines charged and unreactive, spermine was coupled at $\mathrm{pH} 9.5 \pm 0.2$.

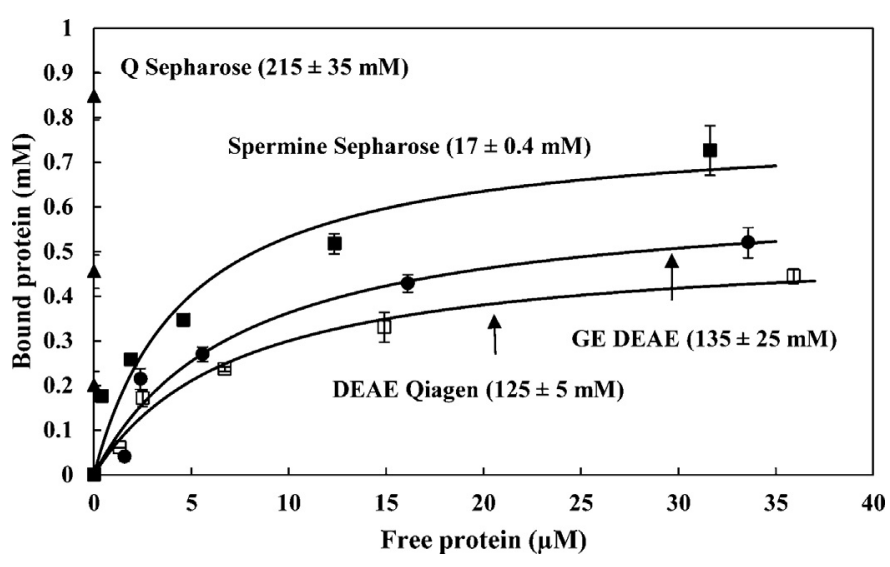

Fig. 2. Adsorption isotherms of $\alpha$-lactalbumin $\left(\mathrm{Ca}^{2+}\right.$ depleted) on $\mathrm{Q}$ Sepharose resin

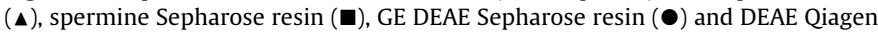
resin ( $\square), 25^{\circ} \mathrm{C}$ in $10 \mathrm{mM}$ Tris, $10 \mathrm{mM} \mathrm{NaCl}, \mathrm{pH}$ 8. Numbers in parenthesis refer to the reported ligand density of each resin according to provider specifications or our measurements. Error bars reported refer to the mean \pm 1 SD.

\subsection{Adsorption isotherm measurements}

$\alpha$-Lactalbumin is a popular model system for study of protein adsorption and chromatography [29-31]. Like at least 30\% of eukaryotic proteins [32], it is a molten globule under physiological conditions, but it is compact and not hydrophobic [33-36]. $\alpha$-Lactalbumin has a conserved $\mathrm{Ca}^{2+}$ binding domain (dissociation constant of $10^{-7} \mathrm{M}$ ) [37], rich in aspartate residues located at the interface between the two subdomains of the protein [38]. In the $\mathrm{Ca}^{2+}$-depleted form of $\alpha$-lactalbumin, repulsion among these residues increases the solvent accessibility of this anionic charge patch.

The maximum binding capacity $\left(Q_{\max }\right)$ and initial binding affinity $\left(Q_{\max } / K_{\mathrm{D}}\right)$ were compared for the spermine Sepharose adsorbent and for conventional commercial adsorbents. As shown in Fig. 2 and Table 1, the lower-ligand-density ( $17 \mathrm{mM}$ ligand) charge-clustered spermine Sepharose adsorbent gave a higher protein binding capacity $\left(Q_{\max }=0.8 \pm 0.1 \mathrm{mM}\right)$ and initial binding affinity $\left(Q_{\max } / K_{\mathrm{D}}=0.17\right)$ than DEAE Qiagen adsorbent (with $125 \mathrm{mM}$ charge density [20]; $Q_{\max }=0.5 \pm 0.04 \mathrm{mM} ; Q_{\max } / K_{\mathrm{D}}=0.07$ ) and the GE DEAE Sepharose (with $135 \mathrm{mM}$ charge density; $\left.Q_{\max }=0.6 \pm 0.08 \mathrm{mM} ; Q_{\max } / K_{\mathrm{D}}=0.08\right)$.

The much lower ligand and charge density of the spermine adsorbent should be emphasized in these comparisons, as it strongly affects protein adsorption [39]. Wu and Walters [40] established that increased ligand density increased lysozyme adsorption in carboxylate-based cation-exchange supports. This behavior has also been discussed for large molecular weight molecules such as monoclonal antibodies [41]. For the GE DEAE Sepharose adsorbent tested, the average through-space distance (which probably slightly over-estimates the actual distance because ligands often are somewhat confined to a specific surface area) between ligands is $23 \AA$ vs. $46 \AA$ for the spermine Sepharose adsorbent. The equivalent spherical diameter for $\alpha$-lactalbumin is $32 \AA$ [42], which could imply that the commercial adsorbent forms an increased number of interactions with the target molecule as compared to spermine Sepharose. Nevertheless, the more widely separated ligands of the spermine Sepharose resin show higher affinity and binding capacity than the GE DEAE resin, supporting the idea that the clustered-charge approach provides enhanced protein adsorption. It is worthy of note that if the ligand density of the clustered spermine adsorbent were increased to densities typical of commercial adsorbents, interactions between ligands would create a more complicated landscape of adsorption sites. Every charge, however, 
Table 1

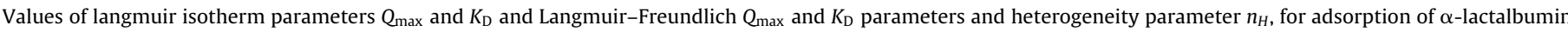
$\left(\mathrm{Ca}^{2+}\right.$ depleted) on spermine-Sepharose, DEAE Qiagen and GE DEAE Sepharose adsorbents.

\begin{tabular}{|c|c|c|c|c|c|c|}
\hline \multirow[t]{2}{*}{ Resin } & \multicolumn{3}{|c|}{ Langmuir isotherm parameters } & \multicolumn{3}{|c|}{ Langmuir Freundlich parameters } \\
\hline & $Q_{\max }(\mathrm{mM})$ & $K_{\mathrm{D}}(\mu \mathrm{M})$ & $Q_{\max } / K_{\mathrm{D}}$ & $n_{\mathrm{H}}$ & $K_{\mathrm{D}}(\mu \mathrm{M})$ & $Q_{\max }(\mathrm{mM})$ \\
\hline \multicolumn{7}{|l|}{ Spermine Sepharose } \\
\hline $10 \mathrm{mM} \mathrm{NaCl}$ & $0.8 \pm 0.1$ & $4.7 \pm 2.0$ & 0.17 & $0.5 \pm 0.1$ & $121 \pm 4$ & $2.0 \pm 0.6$ \\
\hline $26 \mathrm{mM} \mathrm{NaCl}$ & $0.6 \pm 0.1$ & $13.3 \pm 2.7$ & 0.045 & $0.6 \pm 0.01$ & $94 \pm 8$ & $1.2 \pm 0.0$ \\
\hline $40 \mathrm{mM} \mathrm{NaCl}$ & $0.9 \pm 0.4$ & $73.4 \pm 40.1$ & 0.012 & $0.8 \pm 0.02$ & $292 \pm 2$ & $1.9 \pm 0.1$ \\
\hline $60 \mathrm{mM} \mathrm{NaCl}$ & $0.5 \pm 0.2$ & $71.2 \pm 46.9$ & 0.007 & $0.8 \pm 0.1$ & $225 \pm 4.7$ & $0.94 \pm 0.0$ \\
\hline \multicolumn{7}{|l|}{ DEAE Qiagen } \\
\hline $10 \mathrm{mM} \mathrm{NaCl}$ & $0.5 \pm 0.1$ & $7.4 \pm 1.7$ & 0.07 & $0.8 \pm 0.2$ & $12 \pm 2$ & $0.63 \pm 0.2$ \\
\hline $26 \mathrm{mM} \mathrm{NaCl}$ & $0.5 \pm 0.04$ & $14.0 \pm 2.7$ & 0.035 & $0.9 \pm 0.3$ & $20 \pm 4$ & $0.55 \pm 0.2$ \\
\hline $40 \mathrm{mM} \mathrm{NaCl}$ & $0.4 \pm 0.03$ & $12.9 \pm 2.4$ & 0.031 & $1.4 \pm 0.3$ & $10 \pm 2$ & $0.3 \pm 0.03$ \\
\hline $60 \mathrm{mM} \mathrm{NaCl}$ & $0.3 \pm 0.01$ & $9.6 \pm 1$ & 0.031 & $1.0 \pm 0.1$ & $8 \pm 2$ & $0.27 \pm 0.03$ \\
\hline \multicolumn{7}{|l|}{ DEAE GE Healthcare } \\
\hline
\end{tabular}

would be located in a cluster energetically competent to serve as a functional adsorption site.

The low ligand density used raises the possibility that the ligands may be localized to the outer layers of the agarose particles. We do not, however, expect the formation of ligand clusters which significantly modify adsorption behavior, based on the following calculation: Assuming that the spermine ligand is only localized in the outer $3 \%$ of the radius of the beads (mean bead diameter is $90 \mu \mathrm{m}$ ) the average inter-ligand distance would be $20.4 \AA$, whereas assuming uniform ligand distribution the average inter-ligand distance would be 46.1 A. Given that the equivalent spherical diameter of $\alpha$-lactalbumin protein is $32 \AA$ [42], in either case at a given spot there would be no more than two ligands that could interact with the protein, except at rare statistical clusters which would not support the observed protein capacity.

We also analyzed the adsorption data by the steric mass action (SMA) model of Cramer et al. [24] which is based on the stoichiometric displacement model of Regnier et al. [43] (Table 2). Fitting of the 4-parameter SMA model to the data set gave inconsistent convergence. To resolve this issue, we set as initial guesses in the SMA fitting, the Langmuir $Q_{\max }$ and $K_{\mathrm{D}}$ parameters as SMA $Q_{\mathrm{a}}$ and $K$, respectively and estimated values of $v$ and $\sigma$ values. The SMA steric factor $(\sigma)$, which reflects the number of sites on the surface shielded by an adsorbed protein, is 10 -fold lower for spermine Sepharose than for the GE and Qiagen DEAE adsorbents, which have 7.9 and 7.4-fold higher ligand densities, respectively. We ascribe most or all of this difference to the difference in ligand density, any effect of clustering would best be determined using a spermine adsorbent of much higher ligand density, at which inter-ligand interactions might, however, become important.

Salt effects upon protein binding also were studied. Fig. 3a and b present $\alpha$-lactalbumin adsorption isotherms at four different $\mathrm{NaCl}$ concentrations $(10-60 \mathrm{mM})$. At the lower salt concentrations tested (10 and $26 \mathrm{mM} \mathrm{NaCl}$ ), both the initial binding affinity $\left(Q_{\max } / K_{\mathrm{D}}\right)$ and maximum binding capacity $\left(Q_{\max }\right)$ were higher for the spermine adsorbent when compared to the Qiagen DEAE: 2.4 and 1.3 fold higher in $Q_{\max } / K_{\mathrm{D}}$ at 10 and $26 \mathrm{mM}$ and 1.6 and 1.2 fold higher in the maximum binding capacity. For the 40 and $60 \mathrm{mM} \mathrm{NaCl}$ concentrations, the initial binding affinity was higher for the DEAE adsorbent; clustered spermine adsorbent exhibits an increased sensitivity to salt concentration. This characteristic is important in elution-based chromatography since a stronger dependence of adsorption affinity on salt concentration may imply higher resolution capabilities in column mode chromatographic operations.

Salt concentration effects can also be described by the $Z$ plot derived from the stoichiometric displacement model $[40,44]$, as presented in Fig. 4. This graphical representation often exhibits a linear relationship between the logarithm of the initial binding affinity $\left(Q_{\max } / K_{\mathrm{D}}\right)$ of an adsorbent and the logarithm of the salt concentration employed. The slope for this plot gives the apparent numbers of interaction sites, $Z$, of the protein surface with the stationary phase. In our original investigation of clustered adsorbents, the $\alpha$-lactalbumin $Z$ value for pentalysinamide was $1.4 \pm 0.2$ (vs. $1.2 \pm 0.2$ for the unclustered monolysinamide adsorbent of the same total charge) and that for pentaargininamide was $1.0 \pm 0.1$ (vs. $0.3 \pm 0.1$ for the non-clustered monoargininamide of the same
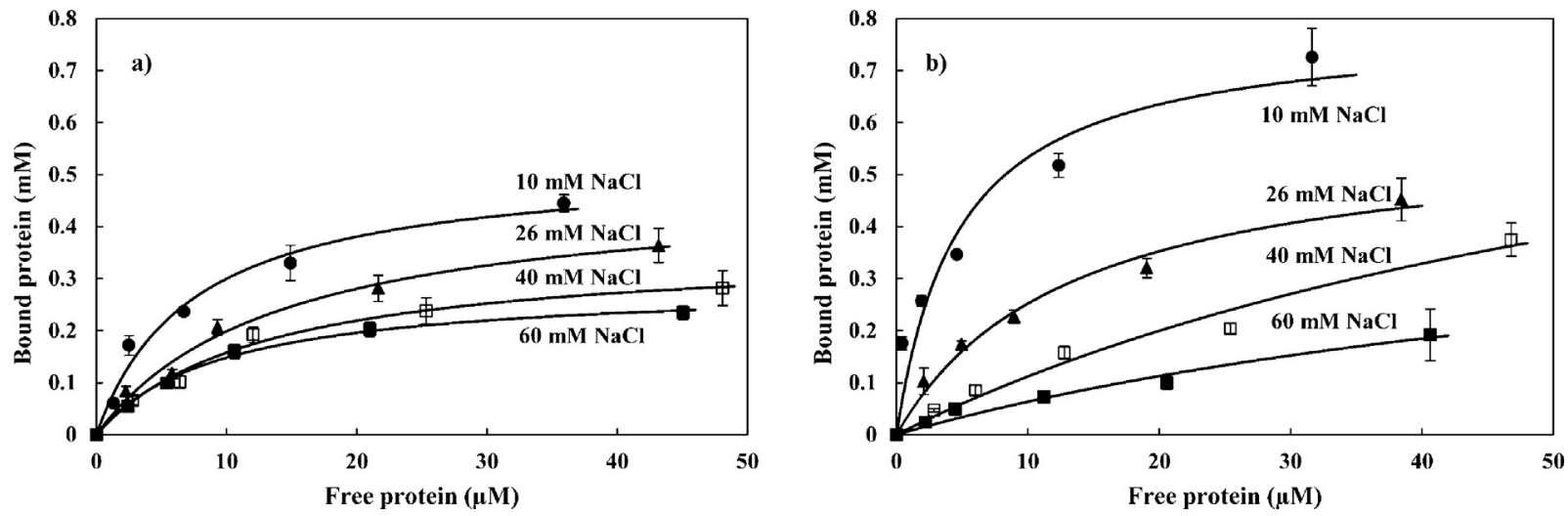

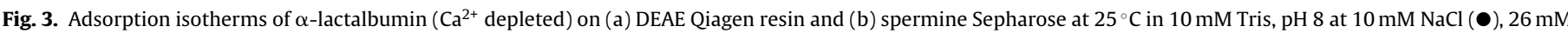
$\mathrm{NaCl}(\boldsymbol{\Delta}), 40 \mathrm{mM} \mathrm{NaCl}(\square)$ and $60 \mathrm{mM} \mathrm{NaCl}(\boldsymbol{\square})$. Error bars reported refer to the mean $\pm 1 \mathrm{SD}$. 
Table 2

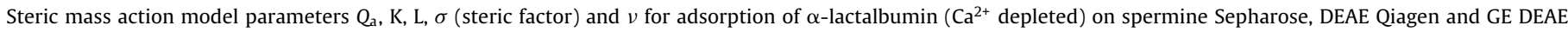
Sepharose adsorbents.

\begin{tabular}{|c|c|c|c|c|c|}
\hline Resin & $Q_{a}(\mathrm{mM})$ & $K(\mu \mathrm{M})$ & $\Lambda(\mathrm{mM})$ & $\sigma$ & $v$ \\
\hline \multicolumn{6}{|c|}{ Spermine Sepharose } \\
\hline $10 \mathrm{mM} \mathrm{NaCl}$ & $0.8 \pm 0.1$ & $4.7 \pm 2.0$ & $17 \pm 0.4$ & $21 \pm 0.1$ & $0.4 \pm 0.6$ \\
\hline $26 \mathrm{mM} \mathrm{NaCl}$ & $0.6 \pm 0.1$ & $13.3 \pm 2.7$ & $17 \pm 0.4$ & $28 \pm 0.1$ & $0.5 \pm 0.1$ \\
\hline $40 \mathrm{mM} \mathrm{NaCl}$ & $0.9 \pm 0.4$ & $73.4 \pm 40.1$ & $17 \pm 0.4$ & $17 \pm 0.8$ & $0.7 \pm 0.1$ \\
\hline $60 \mathrm{mM} \mathrm{NaCl}$ & $0.5 \pm 0.2$ & $71.2 \pm 46.9$ & $17 \pm 0.4$ & $31 \pm 0.5$ & $0.7 \pm 0.1$ \\
\hline \multicolumn{6}{|l|}{ DEAE Qiagen } \\
\hline $10 \mathrm{mM} \mathrm{NaCl}$ & $0.5 \pm 0.1$ & $7.4 \pm 1.7$ & $125 \pm 5$ & $239 \pm 0.6$ & $0.4 \pm 0.1$ \\
\hline $26 \mathrm{mM} \mathrm{NaCl}$ & $0.5 \pm 0.04$ & $14 \pm 2.7$ & $125 \pm 5$ & $261 \pm 0.3$ & $0.5 \pm 0.1$ \\
\hline $40 \mathrm{mM} \mathrm{NaCl}$ & $0.4 \pm 0.03$ & $12.9 \pm 2.4$ & $125 \pm 5$ & $338 \pm 0.6$ & $0.5 \pm 0.1$ \\
\hline $60 \mathrm{mM} \mathrm{NaCl}$ & $0.3 \pm 0.01$ & $9.6 \pm 1$ & $125 \pm 5$ & $430 \pm 0.2$ & $0.4 \pm 0.1$ \\
\hline \multicolumn{6}{|c|}{ DEAE GE Healthcare } \\
\hline $10 \mathrm{mM} \mathrm{NaCl}$ & $0.6 \pm 0.1$ & $7.5 \pm 2.6$ & $135 \pm 25$ & $211 \pm 0.7$ & $0.5 \pm 0.1$ \\
\hline
\end{tabular}

total charge) [11]. In the present investigation, the $Z$ value for the spermine-based adsorbent was $2.2 \pm 0.3$, compared to $0.3 \pm 0.02$ for the DEAE Qiagen adsorbent. Each of these observations is consistent with the idea that clustered-charge adsorbents form a larger number of intermolecular interactions with the adsorbate, thus presenting a higher $Z$ value and increased protein adsorption.

The Langmuir-Freundlich heterogeneity index for spermine Sepharose in $10 \mathrm{mM} \mathrm{NaCl}(0.5 \pm 0.1)$ was substantially lower than those for the dispersed-charge adsorbents, DEAE Qiagen and DEAE Sepharose $(0.8 \pm 0.2$ and $1.2 \pm 0.1$, respectively). In our previous work [11], we also observed a lower heterogeneity index for the clustered charged adsorbent as compared to the dispersed-charge. This behavior is striking in view of the chemical uniformity of the charge clusters in the clustered adsorbent, and likely reflects local variations in steric accessibility, surface entropy, etc. (we recently have observed substantial variations in the kinetic properties of individual functionally defined binding sites using single-molecule fluorescence observations, unpublished). It is also observed that increases in salt concentration favor an increase in the heterogeneity index toward unity of the spermine Sepharose adsorbent. One possible explanation is that salt-mediated shielding of low affinity interactions eliminate them from the functional population [45].

As clustered adsorbents show selectivity toward proteins displaying clusters of charge, it might be expected that they also would show high affinity toward nucleic acids, and indeed we found that pentaargininamide clustered ligands exhibit high affinity for nucleic acids [20]. The biological function of spermine involves pseudospecific packing interactions with DNA [46], and it has been used in purification of DNA, and spermine agarose has been previously shown to have high affinity for DNA [47-49].

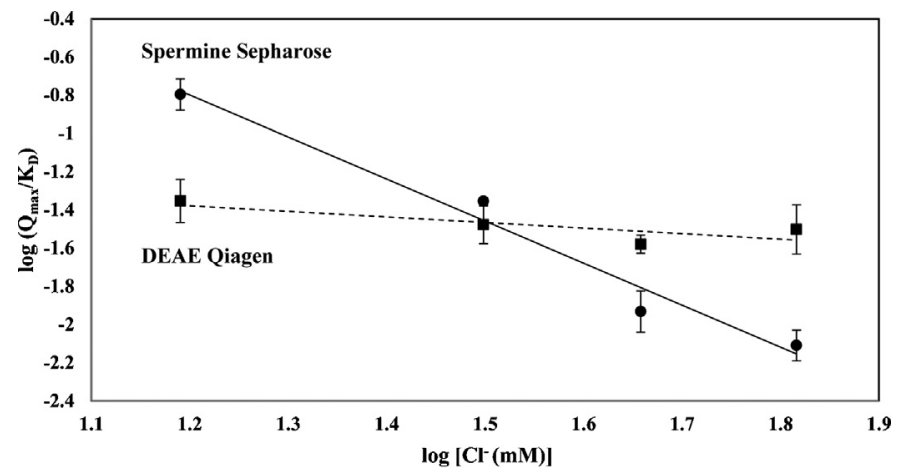

Fig. 4. $Z$ plots for determining the value of the stoichiometric displacement parameter $Z$ for adsorption of $\alpha$-lactalbumin $\left(\mathrm{Ca}^{2+}\right.$ depleted) on spermine Sepharose ( $)$ and DEAE Qiagen ( $)$ in $10 \mathrm{mM}$ Tris, $\mathrm{pH} 8$ at $10,26,40$ and $60 \mathrm{mM} \mathrm{NaCl}$. $Z_{\text {spermine: }}$ : $2.2 \pm 0.3$ and $Z_{\mathrm{DEAE}}: 0.3 \pm 0.02$.
We confirmed the high pseudospecific affinity of spermine agarose for (salmon sperm) DNA (results not shown), and also measured the adsorption of (total baker's yeast) RNA on spermine adsorbents, where ion-exchange interactions would be expected to dominate. As shown in Fig. 5 and Table 3, spermine Sepharose showed a higher RNA binding capacity $\left(Q_{\max }=9.2 \pm 0.9 \mathrm{mg} / \mathrm{mL}\right.$ adsorbent $)$ and a higher binding affinity $\left(Q_{\max } / K_{\mathrm{D}}=642 \mathrm{~mL} / \mathrm{mL}\right.$ adsorbent $)$ than a $1.2 \mathrm{mM}$ pentaargininamide adsorbent previously developed $\left(Q_{\max }=2.1 \pm 0.1 \mathrm{mg} / \mathrm{mL}\right.$ adsorbent; $Q_{\max } / K_{\mathrm{D}}=395 \mathrm{~mL} / \mathrm{mL}$ adsorbent) [20]. Finally, in terms of economic comparison, spermine represents a much more economical approach to synthesis of clustered-charge adsorbents than pentaargininamide.

\subsection{Column chromatography}

To show the applicability of spermine Sepharose in column mode we demonstrated the separation of two anionic proteins using spermine Sepharose (ligand density $13.2 \pm 0.4 \mathrm{mM}$ or charge density $52.8 \mathrm{mM}$ ) and compared its separation efficiency with GE DEAE (ligand density $135 \pm 25 \mathrm{mM}$ ) (Fig. 6). $1 \mathrm{ml}$ of a mixture of $\alpha$-lactalbumin ( $0.2 \mathrm{mg} ; \mathrm{pI}$ : 4.5 , with a surface charge cluster) and BSA (0.2 mg; $p$ I 4.7) was loaded on the column and eluted with a salt gradient. On the spermine Sepharose column, $\alpha$-lactalbumin elutes at $127 \mathrm{mM} \mathrm{NaCl}$ and $\mathrm{BSA}$ elutes at $184 \mathrm{mM} \mathrm{NaCl}$ whereas on GE DEAE $\alpha$-lactalbumin elutes at $125 \mathrm{mM} \mathrm{NaCl}$ and BSA elutes at $175 \mathrm{mM} \mathrm{NaCl}$. This confirms that spermine Sepharose performs well in column chromatography, even at low ligand densities.

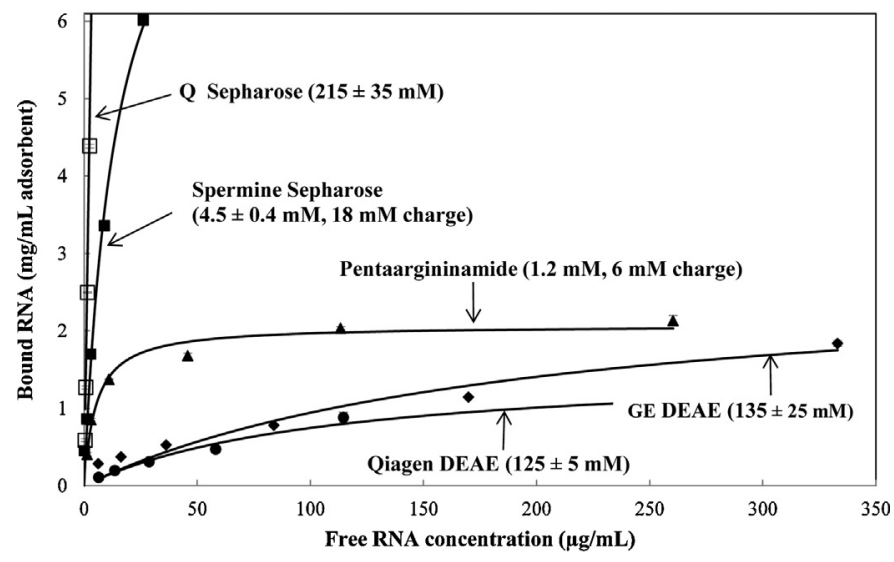

Fig. 5. Adsorption isotherms of Baker's yeast RNA. Langmuir fits for Q Sepharose resin $(\square)$, Spermine Sepharose ( $\square)$, Pentaargininamide adsorbent $(\boldsymbol{\Delta})$, GE DEAE $(\bullet)$, and Qiagen DEAE resin (๑) at $25^{\circ} \mathrm{C}$ in $10 \mathrm{mM}$ Tris, $10 \mathrm{mM} \mathrm{NaCl}$ at pH 8.0. (Results other than spermine Sepharose from Reference [20]). 
Table 3

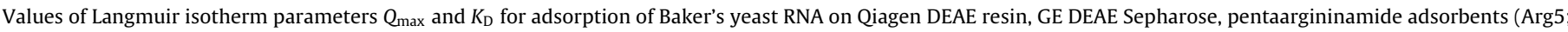
$1.2 \mathrm{mM}$ ligand density), spermine Sepharose and Q Sepharose at $25^{\circ} \mathrm{C}$ in $10 \mathrm{mM}$ Tris, $10 \mathrm{mM} \mathrm{NaCl}$ at pH 8.0. (Results other than spermine Sepharose from Reference [20]).

\begin{tabular}{|c|c|c|}
\hline Adsorbent & $Q_{\max }(\mathrm{mg} / \mathrm{mL}$ adsorbent $)$ & $K_{\mathrm{D}}(\mu \mathrm{g} / \mathrm{mL})$ \\
\hline Qiagen DEAE $(125 \pm 5 \mathrm{mM})$ & $1.6 \pm 0.2$ & $109 \pm 27$ \\
\hline GE DEAE Sepharose $(135 \pm 25 \mathrm{mM})$ & $2.8 \pm 0.7$ & $192 \pm 92$ \\
\hline Pentaargininamide adsorbent ( $1.2 \mathrm{mM}, 6 \mathrm{mM}$ charge $)$ & $2.1 \pm 0.1$ & $5.3 \pm 0.1$ \\
\hline Spermine Sepharose ( $4.5 \pm 0.4 \mathrm{mM}, 18 \mathrm{mM}$ charge $)$ & $9.2 \pm 0.9$ & $14.3 \pm 3.2$ \\
\hline
\end{tabular}

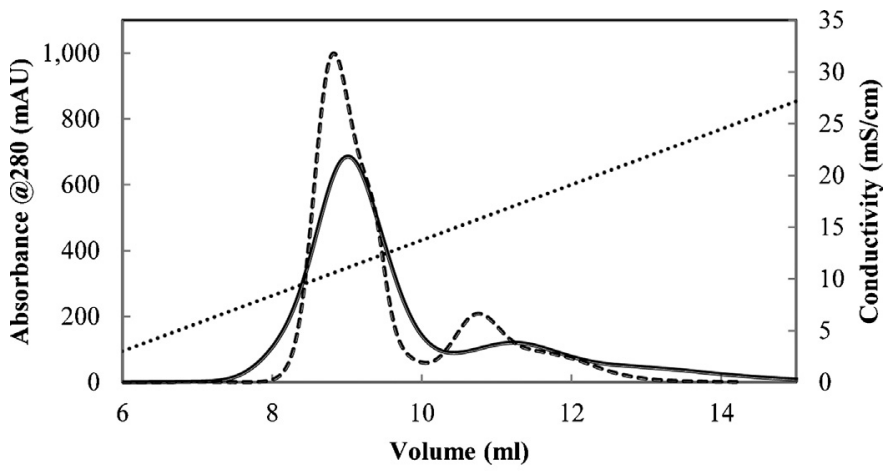

Spermine Sepharose -----GE DEAE …..... Conductivity $(\mathrm{mS} / \mathrm{cm})$

Fig. 6. Linear gradient elution chromatography on spermine Sepharose $(13.2 \pm 0.4 \mathrm{mM}$ ligand or $52.8 \mathrm{mM}$ charge $)$ and GE DEAE $(135 \pm 25 \mathrm{mM})$ of $\mathrm{Ca}^{2+}$ depleted $\alpha$-lactalbumin and BSA. $0.4 \mathrm{mg}(1 \mathrm{ml})$ of protein containing equal amounts of $\mathrm{Ca}^{2+}$ depleted $\alpha$-lactalbumin and BSA were loaded onto a $21 \mathrm{~mm}$ $\mathrm{H} \times 5 \mathrm{~mm}$ ID column on an ÄKTA purifier 10 (GE Healthcare, Uppsala, Sweden). The

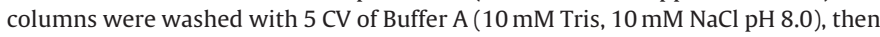
eluted over $25 \mathrm{CV}$ with a linear gradient from Buffer A to Buffer A+250 mM NaCl. On spermine Sepharose $\alpha$-lactalbumin elutes at $127 \mathrm{mM} \mathrm{NaCl}$ whereas BSA elutes at $184 \mathrm{mM} \mathrm{NaCl}$. The proteins were identified based on their retention times when run separately on the same column; absorbance during regeneration with $1 \mathrm{M} \mathrm{NaCl}$ was negligible.

\section{Conclusions}

A clustered-charge spermine Sepharose adsorbent shows high affinity and capacity of protein adsorption even at low ligand densities, and performs well in a column chromatographic separation. The spermine Sepharose adsorbent exhibits higher salt dependency for protein adsorption than conventional DEAE Qiagen adsorbents, raising the possibility of improved resolution of closely related proteins employed in a column mode. Spermine also is more attractive than previous clustered adsorbents in terms of alkali stability and ligand cost. Finally, the high affinity and selectivity of spermine Sepharose support the idea that charge clusters play an important role in ion-exchange adsorption, even on conventional adsorbents.

\section{Acknowledgments}

This research was funded by the Robert A. Welch foundation under Grant E-1264 and the National Science Foundation (NSF) Division of Chemical, Bioengineering, Environmental, and Transport Systems (CBET-1133965). The authors also acknowledge Tecnológico de Monterrey Research chair (Grant CAT161) and CONACyT for fellowship \#295368 to FRR.

\section{References}

[1] J.A. Asenjo, B.A. Andrews, J. Chem. Technol. Biotechnol. 83 (2008) 117.

[2] P.A. Rosa, A.M. Azevedo, S. Sommerfeld, W. Backer, M.R. Aires-Barros, Biotechnol. Adv. 29 (2011) 559
[3] J.R. Birch, A.J. Racher, Adv. Drug Deliv. Rev. 58 (2006) 671.

[4] J. Benavides, O. Aguilar, B.H. Lapizco-Encinas, M. Rito-Palomares, Chem. Eng. Technol. 31 (2008) 838.

[5] J. Benavides, M. Rito-Palomares, J. Chem. Technol. Biotechnol. 83 (2008) 133.

[6] E.R. Langer, J., Bioprocess Int. 4 (2006) 14.

[7] F. Ruiz-Ruiz, J. Benavides, O. Aguilar, M. Rito-Palomares, J. Chromatogr. A 1244 (2012) 1 .

[8] D. Low, R. O’Leary, N.S. Pujar, J. Chromatogr. B: Analyt. Technol. Biomed. Life Sci. 848 (2007) 48.

[9] J.B. Jonathan Albanese, H. Chochois, H. Colin, J. Guillerm, Bioprocess Int. 9(2011) 60.

[10] A. Osberghaus, S. Hepbildikler, S. Nath, M. Haindl, E. von Lieres, J. Hubbuch, J Chromatogr. A 1233 (2012) 54.

[11] J.Y. Fu, S. Balan, A. Potty, V. Nguyen, R.C. Willson, Anal. Chem. 79 (2007) 9060.

[12] P.A. Marichal-Gallardo, M.M. Alvarez, Biotechnol. Progr. 28 (2012) 899.

[13] S. Subramonian, D. Clifford, React. Polym. 9 (1988) 195.

[14] J. Xie, M.-I. Aguilar, M.T.W. Hearn, J. Chromatogr. A 711 (1995) 43.

[15] A. Heeboll-Nielsen, M. Dalkiaer, J.J. Hubbuch, O.R. Thomas, Biotechnol. Bioeng. 87 (2004) 311

[16] J. Ethève, P. Déjardin, M. Boissière, Colloids Surf. B Biointerfaces 28 (2003) 285.

[17] N. Bibak, R.M. Paul, D.M. Freymann, N.R. Yaseen, Anal. Biochem. 333 (2004) 57

[18] D.S. Gill, D.J. Roush, R.C. Willson, J. Chromatogr. A 684 (1994) 55.

[19] D.J. Roush, D.S. Gill, R.C. Willson, J. Chromatogr. A 653 (1993) 207.

[20] W.H. Chen, J.Y. Fu, K. Kourentzi, R.C. Willson, J. Chromatogr. A 1218 (2011) 258.

[21] A.J. Geall, R.J. Taylor, M.E. Earll, M.A. Eaton, I.S. Blagbrough, Bioconjugate Chem. $11(2000) 314$.

[22] S.C. Gill, P.H. von Hippel, Anal. Biochem. 182 (1989) 319.

[23] T. Miron, M. Wilchek, J. Chromatogr. 215 (1981) 55

[24] C.A. Brooks, S.M. Cramer, AIChE J. 38 (1992) 1969.

[25] N.K. Boardman, S.M. Partridge, Biochem. J. 59 (1955) 543.

[26] W. Kopaciewicz, M.A. Rounds, J. Fausnaugh, F.E. Regnier, J. Chromatogr. 266 (1983) 3.

[27] D.S. Gill, D.J. Roush, R.C. Willson, J. Colloid Interface Sci. 167 (1994) 1.

[28] B.N. Palmer, H.K.J. Powell, J. Chem. Soc. Dalton Trans. 29 (1974) 2086

[29] J.M. Bolivar, P. Batalla, C. Mateo, A.V. Carrascosa, B.C. Pessela, J.M. Guisan, Colloids Surf. B Biointerfaces 78 (2010) 140.

[30] R. Lemque, C. Vidal-Madjar, M. Racine, J. Piquion, B. Sebille, J. Chromatogr. 553 (1991) 165.

[31] C. Machold, R. Schlegl, W. Buchinger, A. Jungbauer, J. Chromatogr. A 1080 (2005) 29.

[32] J.J. Ward, J.S. Sodhi, L.J. McGuffin, B.F. Buxton, D.T. Jones, J. Mol. Biol. 337 (2004) 635.

[33] D.A. Dolgikh, L.V. Abaturov, I.A. Bolotina, E.V. Brazhnikov, V.E. Bychkova, R.I. Gilmanshin, O. Lebedev Yu, G.V. Semisotnov, E.I. Tiktopulo, O.B. Ptitsyn, et al., Eur. Biophys. J. 13 (1985) 109.

[34] D.A. Dolgikh, R.I. Gilmanshin, E.V. Brazhnikov, V.E. Bychkova, G.V. Semisotnov, S. Venyaminov, O.B. Ptitsyn, FEBS Lett. 136 (1981) 311.

[35] M. Ohgushi, A. Wada, FEBS Lett. 164 (1983) 21.

[36] C. Redfield, B.A. Schulman, M.A. Milhollen, P.S. Kim, C.M. Dobson, Nat. Struct. Biol. 6 (1999) 948.

[37] D.I. Stuart, K.R. Acharya, N.P. Walker, S.G. Smith, M. Lewis, D.C. Phillips, Nature 324 (1986) 84

[38] E.D. Chrysina, K. Brew, K.R. Acharya, J. Biol. Chem. 275 (2000) 37021.

[39] H.L. Lu, D.Q. Lin, M.M. Zhu, S.J. Yao, J. Sep. Sci. 35 (2012) 2131.

[40] D. Wu, R.R. Walters, J. Chromatogr. 598 (1992) 7.

[41] K. Wrzosek, M. Gramblicka, M. Polakovic, J. Chromatogr. A 1216 (2009) 5039.

[42] A.C. Dumetz, M. Snellinger-O'brien, A.E.W. Kaler, A.M. Lenhoff, Protein Sci. 16 (2007) 1867

[43] W. Kopaciewicz, F. Regnier, Anal. Biochem. 133 (1983) 251.

[44] R.D. Whitley, R. Wachter, F. Liu, N.H.L. Wang, J. Chromatogr. 465 (1989) 137.

[45] M.J. Kronman, Crit. Rev. Biochem. Mol. Biol. 24 (1989) 565.

[46] J.C. Murphy, J.A. Wibbenmeyer, G.E. Fox, R.C. Willson, Nat. Biotechnol. 17 (1999) 822.

[47] J.D. Harding, R.L. Bebee, G. Gebeyehu, Methods Enzymol. 216 (1992) 29.

[48] A. Joachimiak, M. Barciszewska, J. Barciszewski, M. Wiewiorowski, J. Chromatogr. 180 (1979) 157

[49] J.D. Harding, G. Gebeyehu, R. Bebee, D. Simms, L. Klevan, Nucleic Acids Res. 17 (1989) 6947 